\title{
Madness in Vernor Vinge's the Rainbows End
}

\author{
Bahareh Mohammadinasab ${ }^{1} \&$ Hossein Moradi ${ }^{1}$ \\ ${ }^{1}$ Department of English Literature, College of Literature and Languages, Karaj Branch, Islamic Azad University, \\ Alborz, Iran \\ Correspondence: Hossein Moradi, Department of English Literature, College of Literature and Languages, Karaj \\ Branch, Islamic Azad University, Alborz, Iran. E-mail: moradi.hossein@gmail.com
}

\author{
Received: September 28, 2014 Accepted: October 19, 2014 Online Published: November 3, 2014 \\ doi:10.5539/ach.v7n1p171 \\ URL: http://dx.doi.org/10.5539/ach.v7n1p171
}

\begin{abstract}
The major objective of this study is to analysis the concept of madness in Vernor Vinge's The Rainbows End by using Michel Foucault's theory of madness. It is true that Michel Foucault in Madness and Civilization wishes to show us madness in different decades in the past. Having this in mind, I take Foucault's theory of madness as a starting point for analysis of Vinge's The Rainbows End of madness and reason. Furthermore, Vinge manifests the function of madness in 2025. The point is that the concept of madness has a crucial role in our understanding human potentiality during centuries. And Vernor Vinge exercises madman such as Robert who using the language of madness to manifest truth.
\end{abstract}

Keywords: Michel Foucault, Vernor Vinge, madness, reason, alzheimer, dementia

\section{Introduction}

"I had been mad enough to study reason; I was reasonable enough to study madness." Michel Foucault

Foucault by stating this sentence offers that there is no boundary between reason and madness. In his book Madness and Civilization, madness is observed as positive, an object of science, and as a disease. Taking into account that madness called as disease; therefore, they created institutions to the care of mad, in modern age madness has become the object of medical perception. That is the madness is curable. In the novel when Robert awakens from a twenty-year sleep in the year of 2025, with Alzheimer's disease that takes him out of action and much of his physical and mental frailties cures due to new medical research. It is technology that Gu must confront in this case Robert is kept in a clinic in order to be normalized.

Vernor Vinge is a contemporary mathematician, computer scientist, and science fiction writer who focuses on the future world, and he successfully depicts senses of madness and a vast resource of computer power throughout the novel. The researcher chooses Vinge since his work is the outcome of his deep perception of science, and computer power which he manifests in 2025 and Vinge explains how they influence people's life in the next decades. Foucault in Madness and Civilization intends to show us madness in different decades in the past while Vinge displays madness in the next decade. By reading these two works of Vinge's the Rainbows End and Foucault's Madness and Civilization, we perceive the world of mad in different centuries. In this sense, it is argued that the work of Vinge is influential in Michel Foucault ideas. Therefore, the researcher must keep a careful eye on how madness, in a way that Foucault defines, turn out to be productive and make new social behaviors emerge in the character. It is also worth mentioning that regarding productivity of madness, the researcher would take to careful consideration whether those signs of abnormality are apparent on Robert as a technophobic protagonist who finds computers hard to understand and resists against those norms in 2025.

\section{Methodology}

Michel Foucault, a French philosopher, a social critic, a historian, and he is one of the foremost thinkers of the twentieth century. His theories address the relationship between power, knowledge and how they are used as a form of social control through social institutions. He is a main thinker informing the construction of critical theory of new historicism. New historicism frequently addresses the critical theory based upon power. In this respect, the new historians seek to find example of power and how it is present and represented in the text (O'Farrell X).

The methodology is concerned with historical concepts madness in Vinge's The Rainbows End. It is examined in detail through which the researcher opens a horizon for the reader for better understanding of madness which is 
exercised by Robert Gu in2025.The researcher desires to examine how individuals become categorized as normal and abnormal.

\section{Research Questions}

This thesis deals with questions below:

1) How does Robert's resistance toward computational power, bring a kind of misunderstanding?

2) Does Robert's unwillingness in defining his relationship with technology intensify his resistance against the relation of power and control?

3) According to Foucualt's definition of madness, is it a positive characteristic of a person or negative one in 2025 ?

\section{Findings and Implication}

According to Michel Foucault madness has a meaning in different centuries, for instance in Renaissance madness was precious because it spoke of truths, and it interposes between life and death; Madness was a key theme in Shakespeare's works and it plays like a mask for characters such as Hamlet or Katherine in the Taming the Shrew that no one can understand whether they are mad or not. From Foucault point of view, in the very next sentence Vernor Vinge in the Rinbows End pushes the concept of madness by stating: "Robert's been in deep Alzheimer's for almost four years, he's one of the late cures" (97).

Vinge in the novel speaks the language of Foucault's madness that we can see in Robert who is a famous poet and he has inspiration, alienation and posses the Muse that explain as a form of madness, and it seems there is link in his madness and his being a poet, they have united. Robert Gu the one who cured Alzheimer's disease rebels against the Dean Blount who wants to shred the books in library and Gu called them mad and their actions madness. Therefore, in this part the researcher encounters with sane/ insane binary opposition.

\subsection{Madness in the Rainbows End}

Michel Foucault in Madness and Civilization describes "madness begins where the relation of man to truth is disturbed and darkened". According to the different forms of access to the truth, there will be different types of madness. The first type is deliria, which alter that relation to the truth takes shape in perception, it is "general delirium of the mental faculties, in which the diseased perceptions are taken for realities"; the second type is hallucinations, that is the real objects are falsely represented, and the last type is dementias, which without abolishing or altering the faculties that afford access to truth weaken them and diminish their power (104). And in the Rainbows End Robert's behavior does not accord with time and what is common at that times according to Foucault description of madness, he has regarded mad as what Vinge writes in the novel; "Robert was down in the middle of the night, pounding on the door, He thought he was stopping Alice murder. However, he finds it's a false alarm" (161). And his son, Bob figures him tried to beat up Alice. These are the symptoms that display Robert's relation to reality is disturbed, and it manifests his madness as Alice states, "he was a crazy old man, crazy old men have to go to the bathroom all the time" (171).

It appear to exist Robert Gu suffered from dissociative disorders, it is mental disorders. According to Kendra Cherry psychological disorders, also known as mental disorder, are pattern of behavioral or psychological symptoms that impact multiple area of life. As she indicates impulse- control disorder is one of its symptoms that are those involve an inability to control impulses, a resulting in harm to oneself other (3). Robert may experiences anxiety, panic attacks, sleep disorder, obsessive compulsive behavior in the novel which are symptoms of dissociative disorder. Vinge states that "His tongue felt all sticky, his voice hoarse. It suddenly occurred to him that with all the mumbling and darkness maybe he hadn't spoken in some time. And there was something else that was even more strange, who are you? Robert, I'm Miri. I'm your grand--"... (16). Robert reached forward, and her hand was warm in his. "Oh. Cara. It's so good to see you." (19).

While Robert comes back from Alzheimer's disease it seems he travels to new situation, and then he may assume a new life. Therefore, he cannot remember significant person or personal information, and the world around him seems unreal. His feeling toward everyone and everything was uncertain like looking at a strange, and his memory and conscious mind have been disconnected from real world.

There are some changes in Robert, he becomes like child. This can be another symptom of his madness, as Foucault argues: "Madness is childhood. Everything at the retreat is organized so that the insane are transformed into mirror." They are regarded as "children who have an over abundance of strength and make dangerous use of it". They must be given immediate punishment and rewards; whatever is remote has no effect on them. A new system of education must be applied, a new direction given to their ideas. They must be subjugated and encouraged, then applied to work and this work made agreeable by attractive means, for a long time already. The law had 
regarded the insane as mirrors. Great emphasis was placed on the concept of "family" which organized the community of insane and their keepers at the retreat. Apparently this family placed the patient in a both normal and natural; in reality it alienated him still more (Foucault 252). As Vinges manifests in the novel, "The Radners' betting pool on Gu's punishment had been bought out by some guys in LA, Lucky for the twins. The trouble with instant fame was that there was always something new coming to distract everyone's attention" (70).

Vernor Vinge Presents an old man who begins retrain at Fairmont High with his thirteen years old granddaughter and also his partner nine years old Juan Orozco for learning how to live in today's society that he has not recognize because due to the Alzheimer's disease some of his personalities have changed, acting like different, and strange people, including child like behavior.

\subsection{Dementia in the Rainbows End}

Marianne Smith in Behaviors associated with dementia declares that "Alzheimer disease is the most common type of dementia" (43). Although impaired memory and cognitive disturbance are characteristic of all dementias, the specific cognitive, emotional, and behavioral deficits the person with dementia stage of disease, and individual factors, moreover, one or more causes of the older adult suffering from both Alzheimer disease and vascular dementia and causes a mixed symptomatology, in which characteristic losses of more than on disease are seen (41). The term dementia has been related to psychological incompetence. However, the symptoms and explanation of dementia have changed throughout the history.

This explanation has been identified by Vernor Vinge in the Rainbows End, "coming out of years of dementia. Some mornings, his mind was awash with ideas... Yet none of these morning brainstorms contained poetical detail. He had the ideas. He had concepts down to the level of verse blocks. But he didn't have the words and phrases that made ideas into beauty. Making the words sing was the highest, purest talent" (31).

Robert suffered from anxiety disorder which is in the category of dementia. Anxiety disorders are those that are characterized by excessive and abnormal fear, worry, and anxiety which according to Cherry these are symptoms of disorders which occurs to Robert as well. Robert has a sense of detachment from his emotion because due to the Alzheimer's disease he was forgetting his talent and learned skill.

According to what Vinge writes in the novel, we can interpret madness is not a negative force but rather it is a positive force in the story, as Foucault noted that the term "insanity" not as reflecting a single characteristic, but rather a complex variety of psychological reactions. He did not think that insanity could be defined in absolute terms, but rather that it was define in "relativistic terms," depending upon the perceptions of society at a particular time. The term was thus a social construction defined by society according to a flexible series of criteria. Foucault did not regard insanity as a negative characteristic because he felt they those defined as mad often possessed insights into the human condition that could be useful and productive. One difficulty with Foucault's understanding of "insanity", sometimes referred to as the "sociology of knowledge perspective," is that it can lead to a form of relativism. In other words, when we view knowledge as merely constructed by society, then there ceases to be a precise definition of insanity, leaving only a range of definitions depending upon the perception of society at that time (Oliver 89). It seems that Vinge was very much aware of Robert's disease by stating: "sometimes dementia softens a person up. There was a year or so, when Robert was nearly helpless, but he could still recognize people and remember our years together, there was a time when he was tractable... And then they figured how to cure Robert's brand of dementia. By then your grandfather had declined from tractability into a kind of veggie state (110).

For Michel Foucault madness is a term with many layers of interpretations and here in this novel the madness of Robert is a chance to see the truth which is a new success and conquest. Likewise Foucault himself argues that madness is not negative characteristic of a person because Foucault perceives that those who define as mad possessed insight into the human condition frequently which is productive and valuable.

\subsection{Madness as a Self to Truth}

The literary expression of madness serves both to confront madness and to protect man from it. For the humanist poets and philosophers madness is linked not to the world and its "subterranean" forms, but rather to man, to his weakness, his dreams, his illusion (Sheridan 20), that means madness is a deliverance, redemption and emancipation which is generate in humans heart. That kind of madness is novelty since it is not experience before and further more it is not remain the same. As Vinge describes his intentions by stating these sentences in the novel; "There was truth in all that, but for Robert there was another explanation, something weirder and almost as unsettling" (304).

Pascal's reflection is that "men are so necessarily mad that not to be mad would be another form of madness." On the one hand, there is a "mad madness" that rejects the madness proper to reason and which, by doing so, doubles itself and falls into the simplest, most enclosed, most immediate form of madness; and, on the other, a "wise madness" that 
welcomes the madness of reason, allowing it to permeate its whole being, and in doing so protects itself from the real madness that obstinate rejection would bring (21). As we can observe there is a sharp difference between Robert's attitudes at the beginning of the novel which he loses sight of where he is, who he is and it appears to us he is misplaced, in fact he loses his control over life and became untrue to himself. While in the rest of novel, actually at the end of it, he has become true to himself as he mentions at the end of the story "I am happy with the new me" (309). Robert has epiphany by uttering this sentence, he encounters with self-awareness and self-knowledge.

\section{Conclusion}

As Daniel Riha mentions technology is related with both power and knowledge because cyberspace is a social network where people share information with each other and economic strategies play a good game by using human bodies in the virtual space with the technological developments one can see some changes in power strategies and human body (15). The author Vinge defines cyberspace in his science fiction novel the Rainbows $E n d$, and the world which Vinge displays is a computer cosmos. It is a global net-work both computers and humans connected to each other and exchange data in this virtual universe.

Vinge manifests Robert as a mad whose mind and memory have been disconnected from the real world and some of his personalities have changed. However, his madness is chance for him to see the truth in the world that high tech is dominated. Vinge displays technologies which provide construction for human activities, he presents technologies as a powerful force to reshape the meaning of life and modify the pattern of life in future, that is the technology plays a main rule rather than human beings. Therefore, Vinge makes know human death by showing high tech as a superior component to human. As we can consider the total surveillance society which people have controlled by computers and there are technologies that manipulate human's mind such as YGBM, this kind of technologies supply structure for human's life. Thus Vinge presents computer, science and technology are superior to human in the novel. And here in the novel just Robert possessed the insight and could be useful and productive, for him madness is not an absolute term; rather it is defined in relativistic term, depending on the perceptions of society at the particular time according to definition of Foucault. Vernor Vinge's novel is a declaration of human death in 2025 and just Robert, the mad one remains as a human who resists against these high technologies and at the end of novel he feels fine. As Aristotle stated "no great mind has ever existed without a touch of madness." Vernor Vinges chooses Robert, a poet who suffered from Alzheimer and possess inspiration as a protagonist of his novel to manifest that there is truth in madness since the people who are for shred the books and they speak with the language of reason, their action is not reasonable. However, the madman Robert who is against the shredding books seems more reasonable, and we can see the utterance of truth in Robert. In other words, there are links between madness and non-madness, reason and non-reason and they are entangled to each other.

\section{References}

Cherry, K. (2010). The Everything Psychology Book: Explore the human psyche and understand why we do the things we do. Everything Books.

During, S. (1992). Foucault and Litrature. New York: Routledge. http://dx.doi.org/10.4324/9780203358917

Foucault, M. (1961). History of Madness. London and New York: Routledge.

Foucault, M. (1972). Madness and Civilization. New York: Vintage Book.

Foucault, M. (1988). Technologies of the self: A seminar with Michel Foucault. Univ of Massachusetts Press.

Oliver, P. (2010). F.The Key Ideas: Madness and Civilization.

Riha, D., \& Anna, M. (Eds.) (2009). The Real and the Virtual. Oxford: Inter- Disciplinary Press. http://dx.doi.org/10.15340/214733661177

Sheridan, A. (1980). Michel Foucault: the Will to Power. London and New York: Routledge. http://dx.doi.org/10.1111/j.1741-5446.1993.00411.x

Vinge, V. (2006). The Rainbows End. New York: Tom Doherly Associated.

\section{Copyrights}

Copyright for this article is retained by the author(s), with first publication rights granted to the journal.

This is an open-access article distributed under the terms and conditions of the Creative Commons Attribution license (http://creativecommons.org/licenses/by/3.0/). 